\title{
Effect of Compression Ratio on Performance and Emission Characteristics of Dual Spark Plug Ignition Engine Fueled With n-Butanol as Additive Fuel
}

\author{
Ravikumar Ramegouda ${ }^{a^{*}}$ and Antony Alappat Joseph ${ }^{\mathrm{b}}$
}

\author{
aDepartment of Mechanical and Automobile Engineering, SoET, CHRIST (Deemed to be University), Bangalore, India
}

${ }^{b}$ Department of Mechanical Engineering, Mangalore Marine College and Technology, Mangalore, India.

\begin{abstract}
Renewable energy called normal-butanol is a possible alternative fuel for automobile vehicles like some other possible fuel such as compressed natural gas (CNG), liquid petroleum gas (LPG), ethanol, and methanol. Bio-butanol or normal-butanol is also a meritable energy source to substitute for regular fossil fuels. The normal-butanol has recently started to use as a possible substitute fuel to regular fuels for internal combustion engines to attain eco-friendly and capital benefits. As compared to regular energy sources in internal combustion engines, normal-butanol has some benefits, so it shows the potential to decrease tailpipe emission and an increase in positive network delivery. The current work carried out to investigate the performance and emission characteristics of dual spark plug ignition engine fuelled with normal-butanol as additive fuel by adopting 10:1 and 10.5:1 compression ratios. The experimental results reveal that when compared between 10:1 and 10.5:1 compression ratios, brake power (BP) is increased by $3.5 \%$ and $3.2 \%$ for normalButanol 35 (nB35) blend and energy efficiency increased by $2.72 \%$ and $2.14 \%$ for nB35 blend at a part and full load for 10.5:1 compression ratio. The n-butanol create a greater impact on tailpipe emissions that the carbon monoxide (CO) decreased by $32 \%$, $29 \%$, and hydrocarbon (HC) reduced by $2.38 \%$ and $2.22 \%$ for $\mathrm{nB} 35$ blend at a part and full load condition respectively. The experimental results on dual spark ignition engine using $n$-butanol as additive fuel by varying compression ratio reveals that $n$-butanol can be a suitable replacement energy source for the automobile sector in the nearest future.
\end{abstract}

Keywords: Eco-friendly, Efficiency, n-Butanol, Renewable energy, Tailpipe emission.

Article History: Received: $8^{\text {th }}$ August 2020; Revised: 24th Sept 2020; Accepted: 29 ${ }^{\text {th }}$ Sept 2020; Available online: $3^{\text {rd }}$ Oct 2020

How to Cite This Article: Ramegouda, R. and Joseph, A.A. (2021), Effect of Compression Ratio on Performance and Emission Characteristics of Dual Spark Plug Ignition Engine Fueled With n-Butanol as Additive Fuel. Int. Journal of Renewable Energy Development, $10(1)$, 37-45.

https://doi.org/10.14710/ijred.2021.32364

\section{Introduction}

Currently, environmental pollution and emissions from automobile vehicles are the most important concern. The various countries are paying more attention to minimize the exhaust emission such as carbon monoxide (CO), nitrogen oxides (NOx), and hydrocarbon (HC) from an automotive vehicle by adopting new inventions in the design and development of IC engines (Sissine 2007; Demirbas 2009; Hoang \& Le 2017; Kattela et al. 2018; Zhen et al. 2019). Many research results on IC engines reveal that without enhancing the physical, chemical, and thermal properties of fuels it is difficult to achieve greater thermal efficiency, brake power, fuel economy, and reduction in $\mathrm{CO}, \mathrm{NOx}$, and $\mathrm{HC}$ emissions even after modifying the internal combustion engines. (Alasfour 1998a,b,c; Szwaja and Naber 2010; Deng et al. 2013; Elfasakhany 2014; Mohite et al. 2016; Mahfud et al. 2020). On the other hand, fossil fuels are going to exhaust in the nearest future, a suitable replacement fuel for internal combustion engines needs to produce for the sustainable growth of a country that depends on the importing of fossil fuels to meet their citizen's demands. (Sun \& Cheng 2002; Pimentel \& Patzek 2005; Sorda et al. 2010; Amezaga et al. 2018; Hadiyanto et al. 2020). Some of the automobile vehicle manufacturing companies are trying to reduce the production of compression ignition (CI) engines and some are completely stopping to produce because of the recent studies result in higher hydrocarbon (HC) and nitrogen oxide (NOx) emission by compression ignition (CI) engines (Ganesan 2012; Akanaw et al. 2014). After considering all these possible difficulties in the nearby future, we have reasonable responsibilities to adopt a suitable energy source for the spark-ignition engine (Balat \& Balat 2009; Chen et al. (2012a,b,c); Zhu et al. 2014; Atmanl et al. 2014; Murachman et al. 2014). However, an electrical vehicle is also attracting much young research scholar, but the complete substitution of electrical vehicles in the place of the internal combustion engine vehicles is not so easy task in the shortest duration due to some practical difficulties

\footnotetext{
*Corresponding author: r.ravikumar64@gmail.com
} 
in charging time of the battery, charging stations, safety issues, cruising range, distance traveled per charging, and maintenance problem of EV is importantly unveiled (Kuhe \& Aliyu 2017; Kattela et al. 2018; Ravikumar et al. (2018a,b); Zhen et al. 2019). Therefore, the invention and utilization of renewable energy have a good perspective on vehicles (Gao et al. 2007; Yang et al. 2009; Kolokotronis et al. 2010; Dernotte et al. 2010; Potter et al. 2012; Anand et al. 2012). The A-B-E fermentation (Acetone-ButanolEthanol) technology to produce n-butanol from lignocellulose materials is noticed that the cheap and costeffective processing to overcome the high substrate cost problem. It has a possible prospect in the nearby future and it is a promising substitute energy source and its production and transport methods are fetching further mature (Sun \& Cheng 2002; Padhee \& Raheman 2014; Ravikumar \& Antony 2019; Darmayanti, et al. 2020). The current research work carried was out on a dual sparkignition engine by varying compression ratio to verify the suitability of n-butanol as additive fuel with gasoline in terms of achieving better thermal efficiency, brake power, fuel economy, and minimized carbon monoxide, nitrogen oxides, and hydrocarbon emission.

\section{Materials and Methods}

\subsection{Test Rig}

Experimental investigations were carried out on internal combustion, 4-stroke, single-cylinder gasoline engine facilitated with a dual spark plug, variable compression ratio, and coupled with eddy current dynamometer to provide brake load. The $220 \mathrm{cc}$ Bajaj engine is selected for the current research work and all the necessary equipment is arranged such as an exhaust gas analyzer, pressure transducer, loading cell, control units are arranged and assembled. The used facilities specifications are shown in Table 1.

Table 1

Dual spark plug engine test rig and 5-gas analyzer specifications.

\begin{tabular}{|c|c|}
\hline \multicolumn{2}{|c|}{ Dual spark plug engine test rig } \\
\hline Parameter & Description \\
\hline Engine & $\begin{array}{l}\text { 4-Stroke, Oil Cooled, Single } \\
\text { Cylinder }\end{array}$ \\
\hline Engine Displacement (cc) & 220 \\
\hline Power-(bhp@ @rpm) & $20.76 @ 8500$ \\
\hline Torque-(Nm@rpm) & $19.12 @ 7000$ \\
\hline Bore diameter $(\mathrm{mm})$ & 67 \\
\hline Stroke length (mm) & 62.4 \\
\hline Rated Compression Ratio & $9.5: 1$ \\
\hline Number of Valves & 2 \\
\hline Fuel Supply System & Carburetor \\
\hline Valves arrangement & Overhead Camshaft \\
\hline Engine Cooling System & Oil Cooled and Air-Cooled \\
\hline Ignition type & Dual Spark Ignition \\
\hline \multicolumn{2}{|c|}{ 5-gas analyzer } \\
\hline Parameters & Description \\
\hline Make (Brand) & AVL Digas \\
\hline Model & $444 \mathrm{D}$ \\
\hline $\mathrm{CO}$ & $0 \ldots 10 \%$ Vol. \\
\hline $\mathrm{HC}$ & $0 \ldots 20,000 \mathrm{ppm}$ \\
\hline $\mathrm{CO}_{2}$ & $0 \ldots 20 \%$ Vol. \\
\hline $\mathrm{O}_{2}$ & $0 \ldots 22 \%$ Vol. \\
\hline NO & $0 \ldots 5000 \mathrm{ppm}$ \\
\hline
\end{tabular}

\subsection{Methodology}

In this current work, the experimental investigations were carried out on single-cylinder, dual spark plug ignition, the four-stroke engine for two different compression ratios using pure gasoline and blends of n-butanol and gasoline. The percentage of $n$-butanol varied from $5 \%$ to $35 \%$ by volume. The stock compression ratio of the selected engine is $9.5: 1$, so the test rig was modified to operate with 10:1 and 10.5:1 compression ratio to determine the performance and emission characteristics of the dual spark plug ignition engine. The engine test rig is facilitated with two different engine heads alternatively to vary the compression ratio. The obtained results are compared between $10: 1$ and 10.5:1 compression ratio and B00, B05, B10, B15, B20, B25, B30, and B35 fuel samples at the part $(8 \mathrm{~W})$ and full load $(16 \mathrm{~W})$ operating condition.

\section{Results and Discussions}

\subsection{Influence of the compression ratio on the indicated power (IP).}

Figure 1 demonstrates that the positive work developed by the engine at different compression ratios for the pure gasoline and blends of $n$-butanol-gasoline. The results reveal that the compression ratio creates a positive impact on engine performance. The test rig was made to operate with a constant speed of $3000 \mathrm{rpm}$, variable compression ratio, and load varying from $2 \mathrm{~W}$ to $16 \mathrm{~W}$.
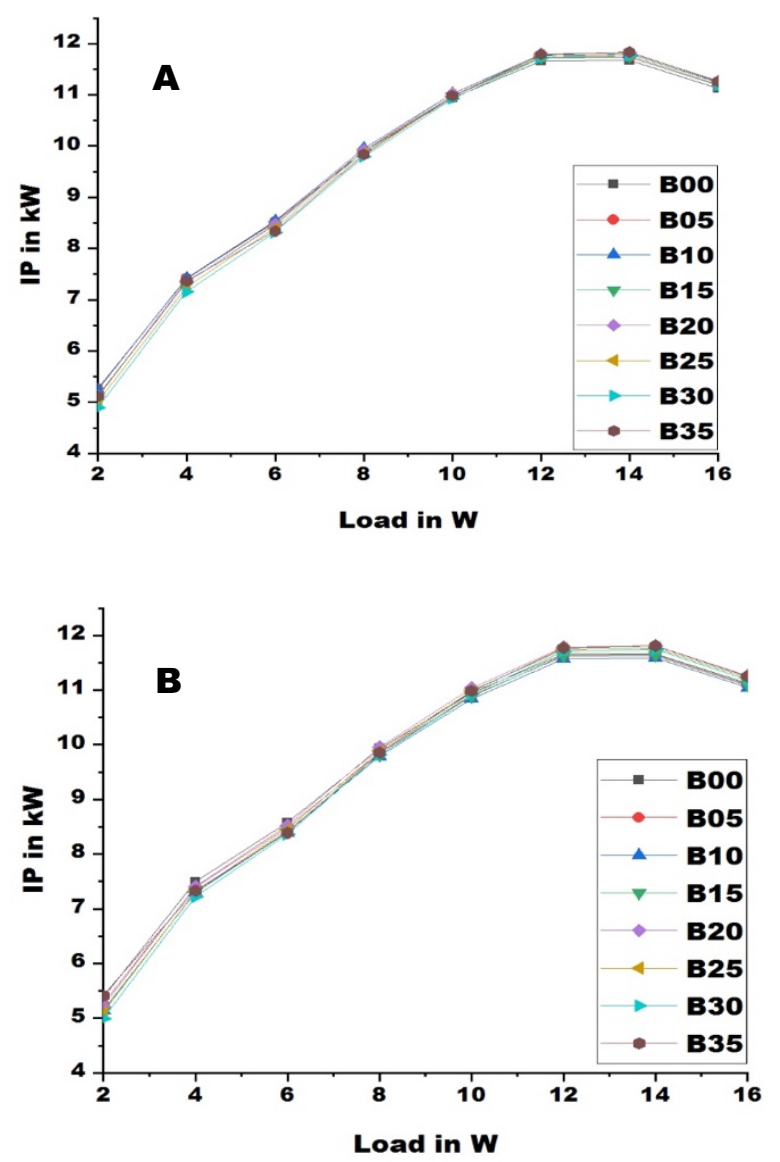

Fig. 1. Influence of CR on indicated power (IP), (A) 10:1 \& (B) 10.5:1 
The obtained results are compared between blends B00, B05, and B35 for both 10:1 and 10.5:1 compression ratio. The fuel blend B05 shows $0.6 \%, 0.89 \%$ higher IP at the part $(8 \mathrm{~W})$, and full load (16W) condition when CR increases from 10:1 to 10.5:1. About $0.2 \%, 0.11 \%$ greater IP obtained for B35 blends at the same operating condition. The greater indicated power results are due to an increase in the compression ratio and presence of $n$ butanol with the mixture.

\subsection{Influence of compression ratio on the brake power (BP).}

The corresponding Figure 2 plotted for different mixtures of $n$-butanol and gasoline at variable CR's. The positive work done by the engine is increased with increasing load as well as the percentage of n-butanol with the mixtures. After the part load, BP starts to decline for all the fuel samples due to the engine got overload. The fuel sample B05 given $3.7 \%$, $3.6 \%$ much power than pure gasoline at the part, and full load condition for 10.5:1 compression ratio. The blend B35, the brake power was found to be 3.5 $\%, 3.2 \%$ increase at the same operating conditions.
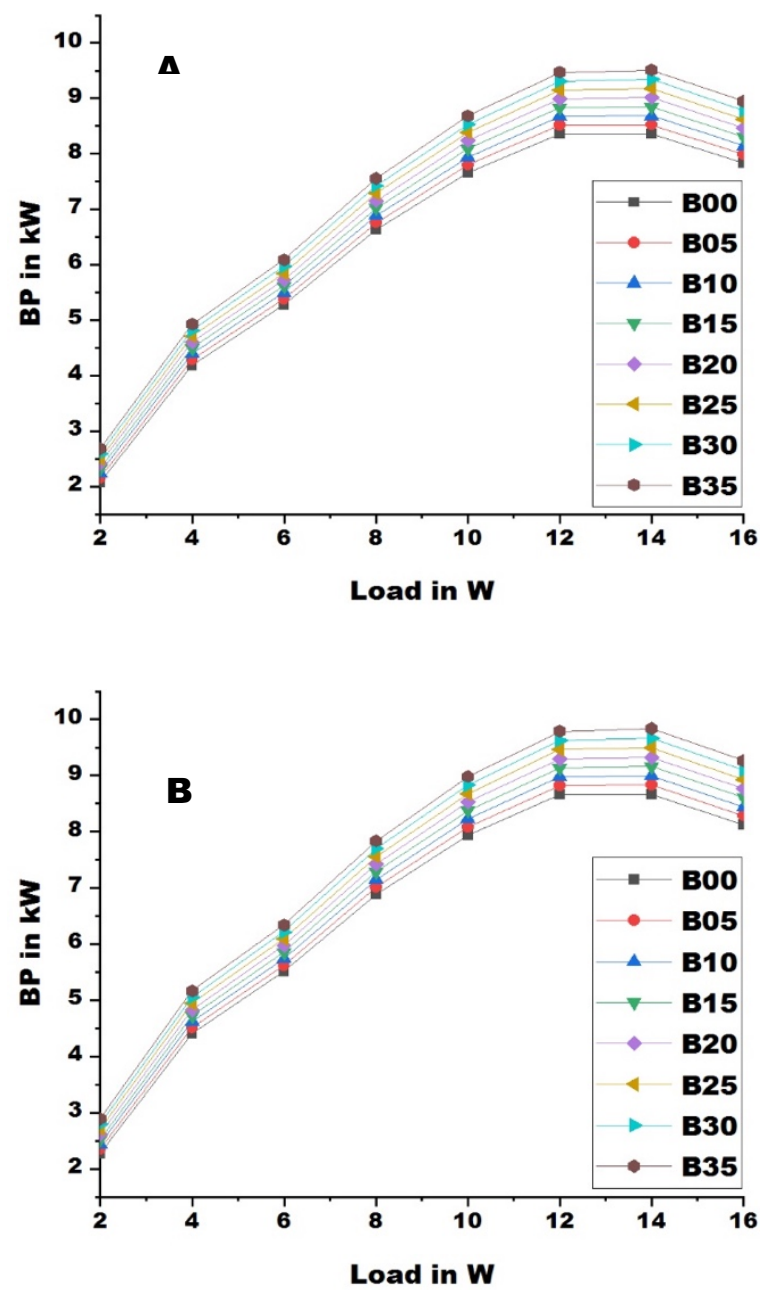

Fig. 2. Influence of CR on brake power (BP), (A) 10:1 \& (B) 10.5:1
The reason behind the increase in brake power is due to the higher compression ratio and the n-butanol in the fuel samples provides sufficient oxygen for complete combustion of fuel which directly contributes to positive power delivery The additional reason is the existence of the second spark plug in the same combustion chamber helps in burning the remaining fuel components when they come in contact with the zonal area of the second spark plug.

3.3 Influence of compression ratio on the brake specific fuel consumption (BSFC).

Figure 3 shows the effect of the compression ratio on brake specific fuel consumption (BSFC) of a test rig for pure gasoline and n-butanol blend with gasoline. It has been noticed that brake specific fuel consumption keeps reducing up to a certain load and starts to increase when the engine is overloaded for both the CR's and fuel samples. BSFC is the amount of fuel consumed by the engine to deliver rated power. In this present study, experimental investigations were conducted on a dual spark-ignition engine by varying CR's and using varieties of fuel samples.
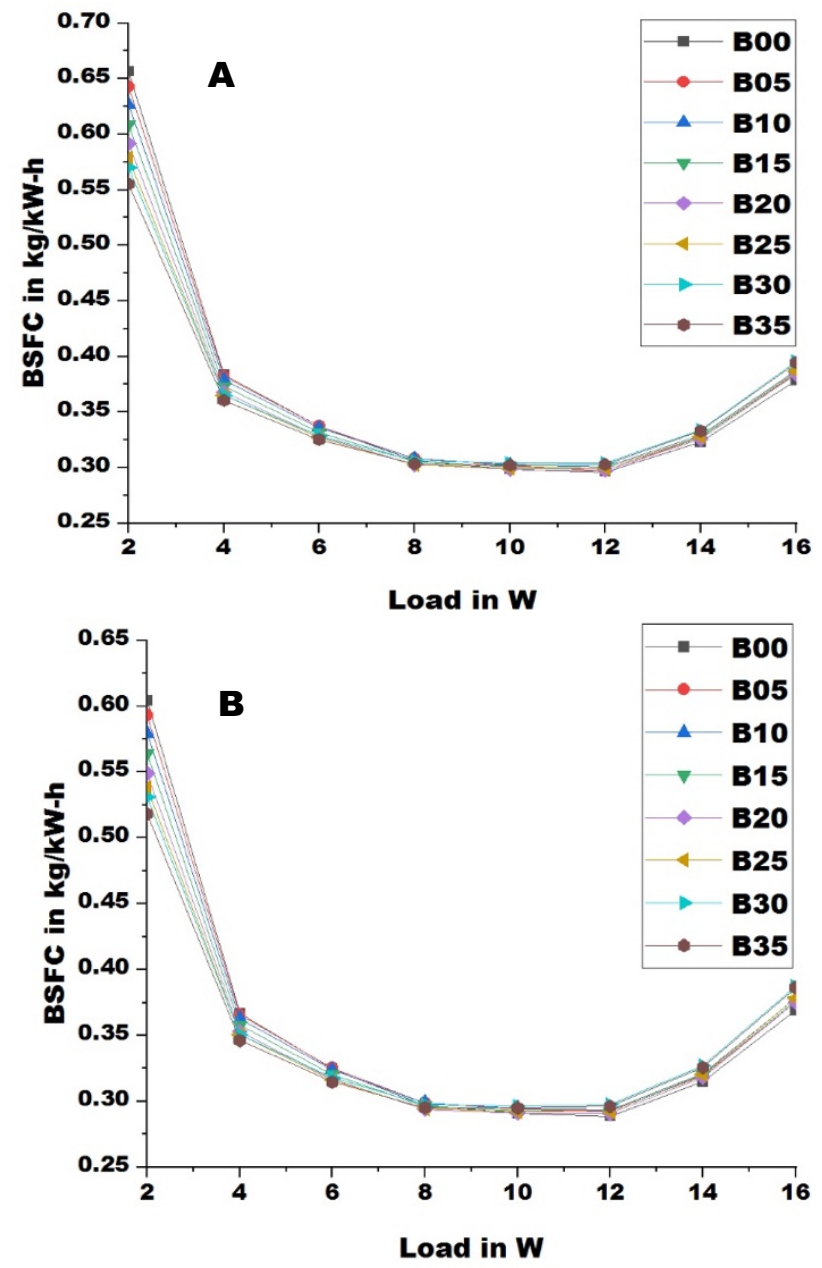

Fig. 3. Influence of CR on brake specific fuel consumption (BSFC) (A) $10: 1 \&$ (B) $10.5: 1$ 
At the initial stage, the device consumes little greater fuel to overcome from all types of resistance and gradually decreases as shown in Figure 5. The results are compared between CR's and fuel samples, it reveals that $06 \%, 0.89$ $\%$ higher fuel consumption for B05 blend at the part, and full load condition. About $0.2 \%$ decreased and $0.11 \%$ higher BSFC noticed for B35 blend at the part and full load respectively. The brake specific fuel consumption is quite increases when the engine is fuelled with fuel blends due to the lower energy density of n-butanol in the blended sample.

\subsection{Influence of compression ratio on the air-fuel ratio.}

The ratio between, the quantity of air required to combust supplied fuel within the combustion chamber is taken into account as an air-fuel ratio. Initially, the engine demands more fuel supply to start and propagate from its rest state. This has happened due to the components of the internal combustion engine chamber itself as it will be exposed to lesser temperature. When combustion begins, the heat starts to dissipate to all the components and becomes higher than that of at-rest temperature. In lowtemperature conditions, the engine demands a little rich mixture.
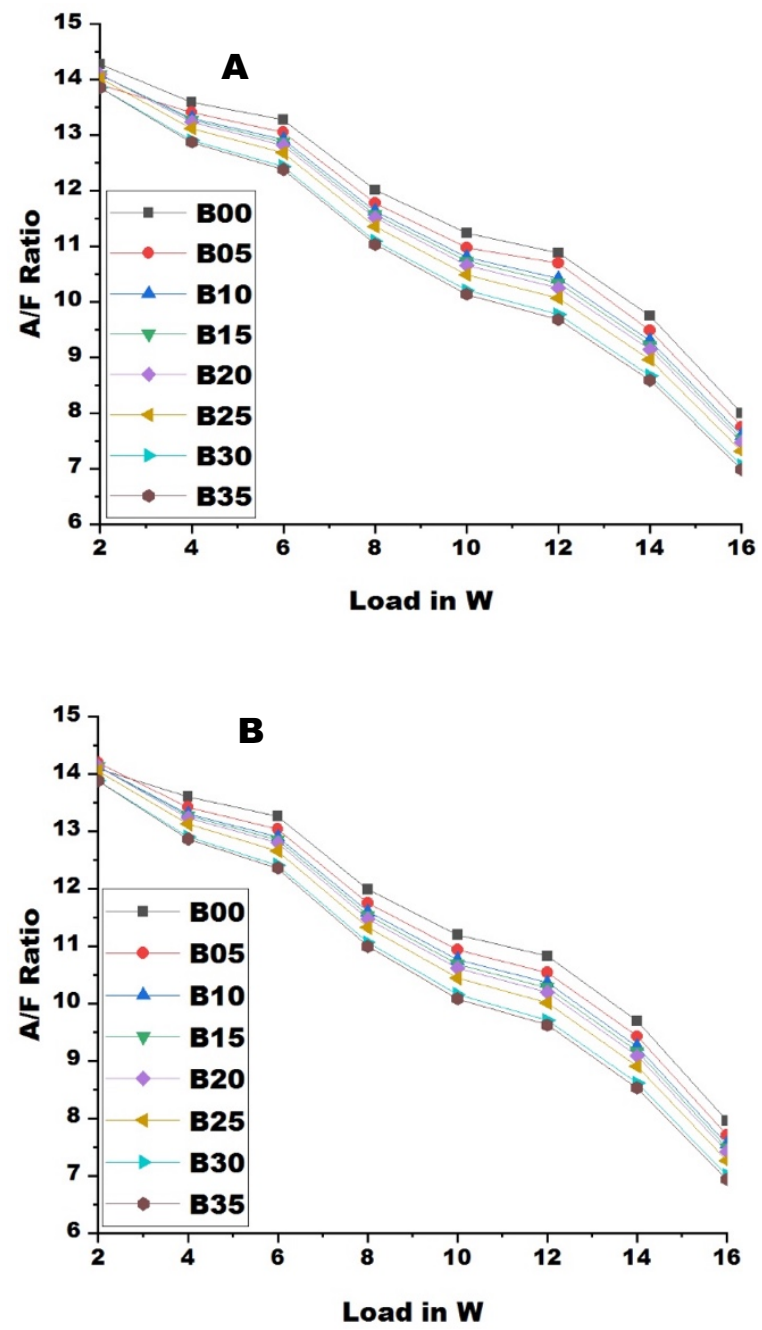

Fig. 4. Influence of CR on air-fuel ratio, (A) 10:1 \& (B) 10.5:1
Further increasing the chamber temperature, a sufficiently lean mixture is enough for developing the necessary quantity of work which is shown in Figure 4. The percentage of n-butanol increases with fuel samples gives a decrease in the Air-Fuel ratio. An amount of 0.25 $\%, 0.64 \%$ reduction for $\mathrm{B} 05$ blend at the part as well as full load condition respectively. The blend B35 shows 0.27 $\%$ and $0.85 \%$ decreased in the Air-Fuel ratio at the same operating condition.

\subsection{Influence of compression ratio on the brake thermal efficiency (Mbte).}

The rate of heat energy utilized by the engine to produce rated power output is called the thermal efficiency of an internal combustion engine. The current experimental results reveal that the brake thermal efficiency of the test rig found to be higher for n-butanol blends as the percentage of n-butanol increases. Figure 5 illustrates the effect of the compression ratio on brake thermal efficiency. The efficiency starts to downfall after crossing the partload level moving towards the full load. The higher brake thermal efficiency results were due to complete combustion achieved within the combustion chamber with the help of hydroxyl group facilitating the additional oxygen.
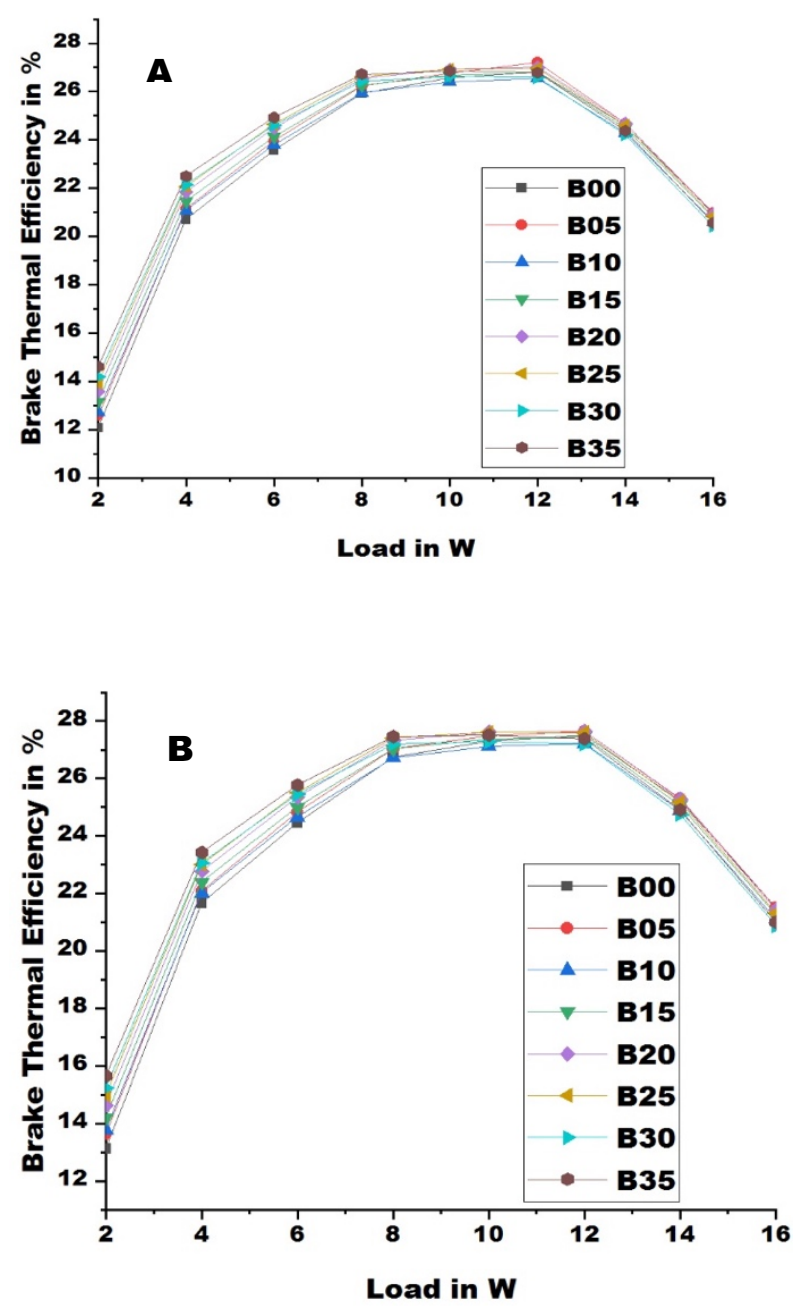

Fig. 5. Influence of CR on brake thermal efficiency (Пbte), (A) 10:1 \& (B) 10.5:1 
The complete combustion contributes to releasing a larger amount of energy which further creates a considerable impact on brake power and brake thermal efficiency. When results are compared, B05 gives $2.99 \%, 2.51 \%$ higher value of BTE, and B35 indicates $2.73 \%, 2.14 \%$ greater brake thermal efficiency at the part, and full load condition respectively.

\subsection{Influence of compression ratio on the volumetric efficiency ( $\left.\eta_{\text {vol }}\right)$.}

Figure 6 (A) \& (B) showcases the volumetric efficiency of the test rig when it was fuelled with gasoline and nbutanol blends as well. Volumetric efficiency is a certain amount of air-fuel mixture entered into the fixed volume of the combustion chamber. The experimental result reveals that the volumetric efficiency of the engine is quite greater than pure gasoline fuel at all the respective operating conditions. The n-butanol in the fuel samples has a higher enthalpy of vaporization which contributes to higher volumetric efficiency. Due to this property, more amount of fuel is admitted into the combustion chamber which directly helps in providing higher volumetric efficiency. About an average of $0.55 \%$ increase in volumetric efficiency is noticed for B05 and B35 blends at the same operational condition.
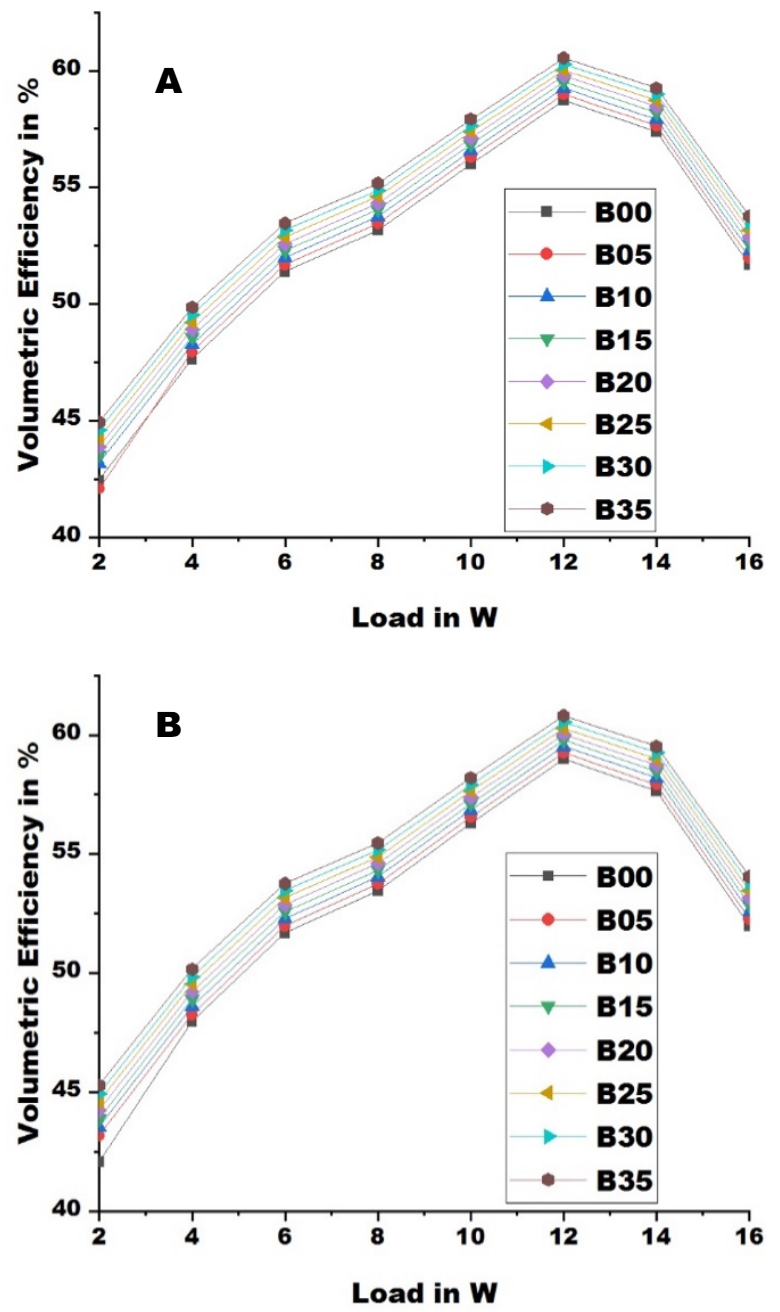

Fig. 6. Influence of $\mathrm{CR}$ on volumetric efficiency $\left(\mathrm{\eta}_{\mathrm{vol}}\right)$, (A) 10:1 \& (B) $10.5: 1$
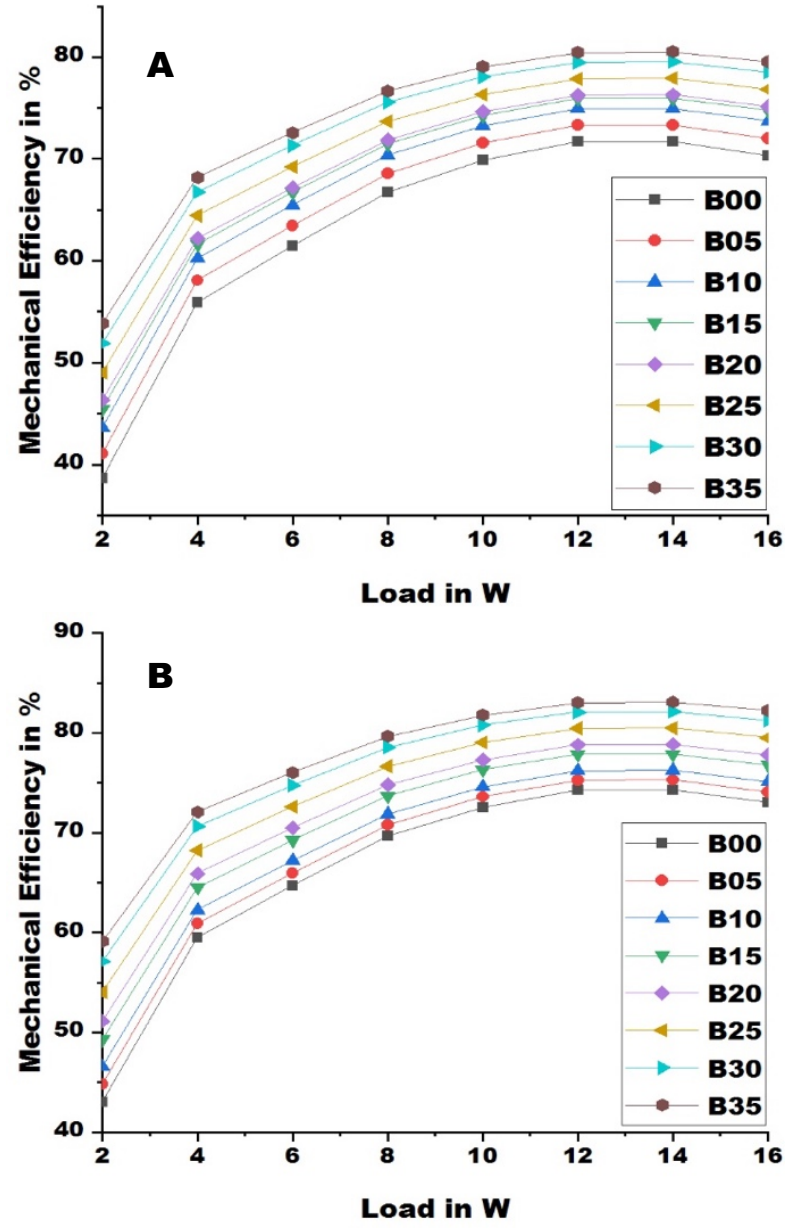

Fig. 7. Influence of CR on mechanical efficiency (Пmech), (A) 10:1 \& (B) 10.5:1

3.7 Influence of compression ratio on the mechanical efficiency ( $\eta$ mech).

The mechanical efficiency is the ratio of brake power and indicated power. The mechanical efficiency of an internal combustion engine will play the main role, the larger number of molecules containing oxygen and hydrogen in fuel blends and the combustion of fuel at the end of combustion proceeds by the secondary spark plug contributes to achieving complete combustion of the fuel. This leads to getting maximum positive power output by the engine which significantly provides higher mechanical efficiency. It is noticed that mechanical efficiency increased for CR 10.5:1 by $1.59 \%, 0.44 \%$ for B05 and 3.76 $\%, 3.27 \%$ for B35 sample at the part, and full load condition respectively.

3.8 Influence of compression ratio on the carbon monoxide (CO) emission.

Carbon monoxide emission is measured for n-butanol blends and noticed that it is dramatically decreased with an increasing percentage of n-butanol and CR. Figure 8 demonstrated the rate of CO emission for 10.1 and 10.5:1 CR's. The decrease in $\mathrm{CO}$ emission is due to the complete combustion of fuel in the combustion chamber with the help of readily available oxygen content with n-butanol blends and additional spark plug in the same chamber. 

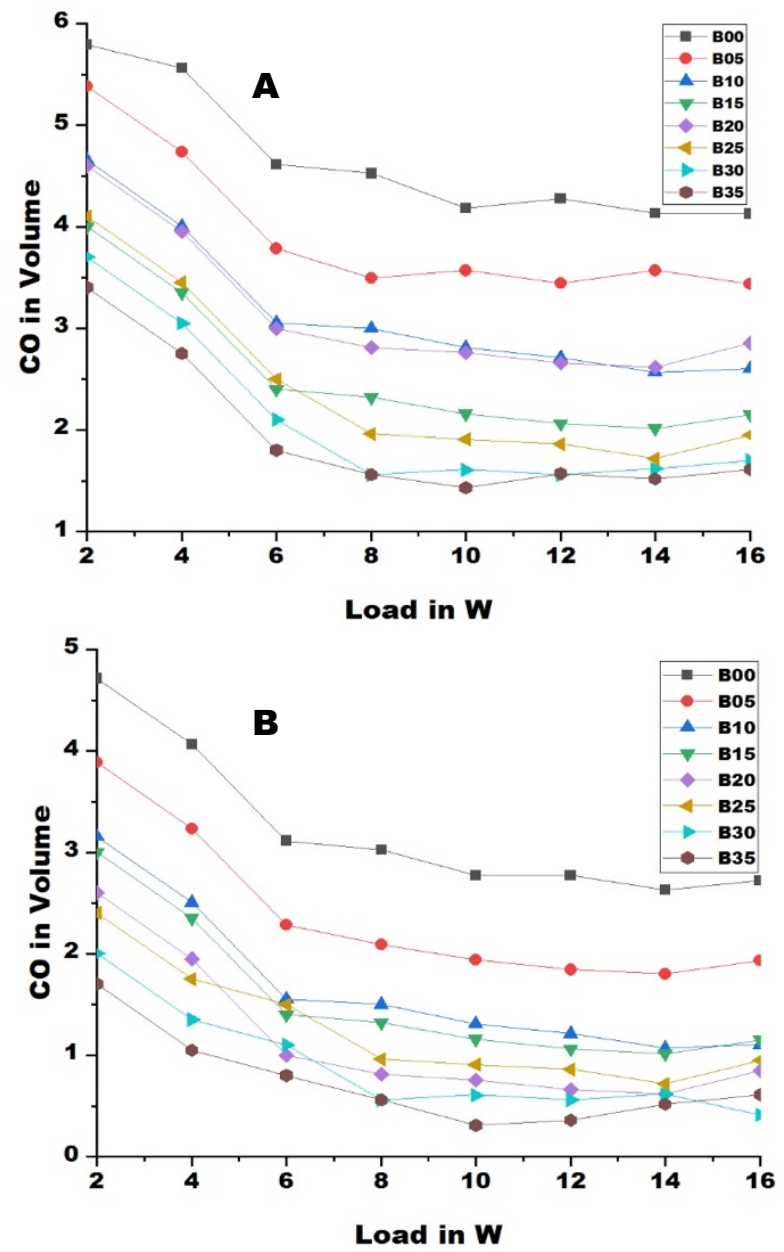

Fig. 8. Influence of CR on carbon monoxide (CO), (A) 10:1 \& (B) $10.5: 1$

The mixture $\mathrm{B} 05$ results in decrease $\mathrm{CO}$ emission by 40.11 $\%$, $43.6 \%$, and $64.71 \%, 62.73 \%$ for B35 sample at the part, and full load operating condition when compared between 10:1, 10.5:1 CR's. This observation is made due to the n-butanol readily available with greater oxygen content and due to lesser adiabatic flame temperature during the fuel combustion process at the combustion chamber.

3.9 Influence of compression ratio on the carbon dioxide $\left(\mathrm{CO}_{2}\right)$ emission.

The investigated results finally conclude that carbon monoxide emission increases for n-butanol mixtures with increasing compression ratio. Figure 9 illustrates the carbon dioxide emission for pure gasoline and n-butanolgasoline blends. In the beginning, all the fuel samples show the least $\mathrm{CO}_{2}$ discharge, an average of $12.73 \%, 14.66$ $\%$ higher from B35, and $10.88 \%, 11.01 \%$ increased for B05 sample while comparing with regular gasoline fuel at the part and full load operating condition. The results reveal that the $\mathrm{CO}_{2}$ emission quite increases with an increased compression ratio of the engine.
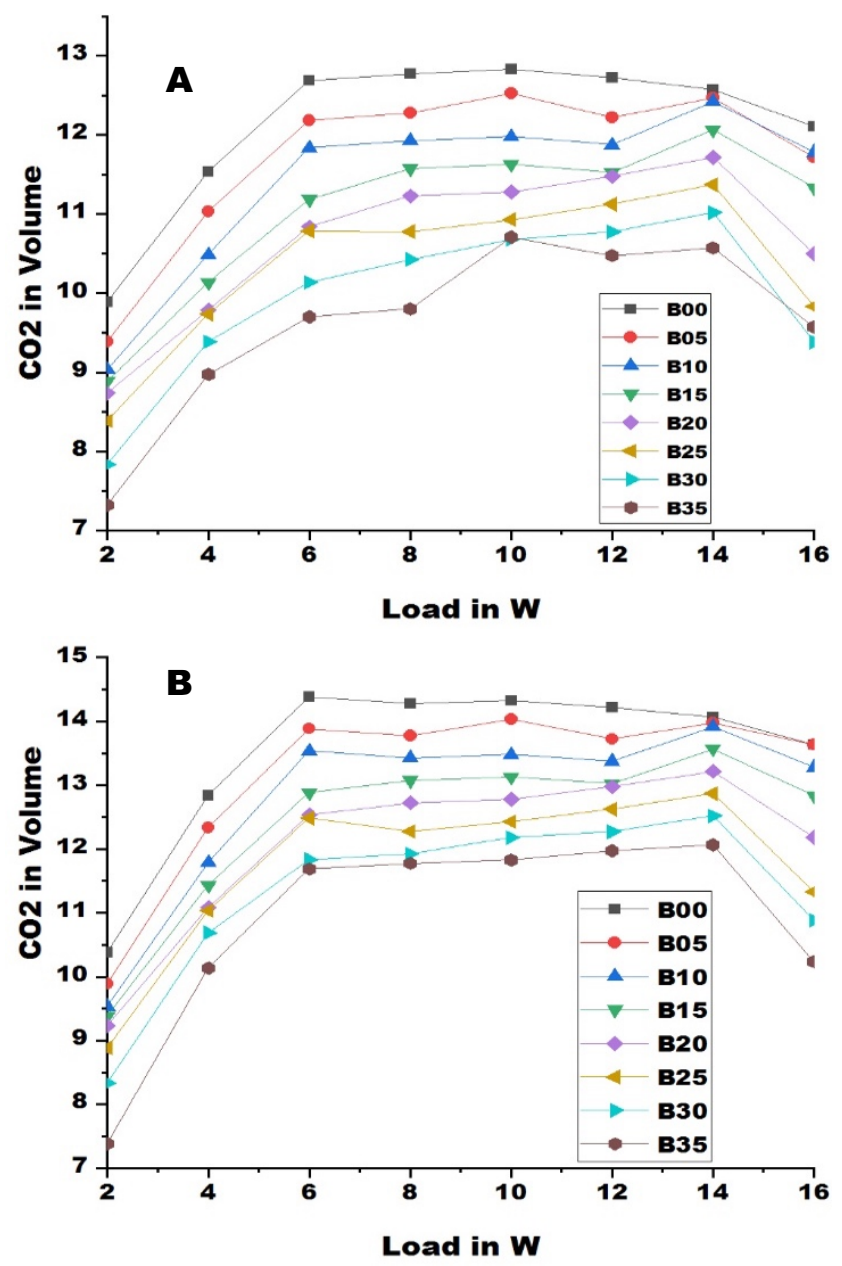

Fig. 9. Influence of $\mathrm{CR}$ on carbon dioxide $\left(\mathrm{CO}_{2}\right)$, (A) 10:1 \& (B) 10.5:1

3.10 Influence of compression ratio on the hydrocarbon (HC) emission.

Hydrocarbon emission due to incomplete combustion of fuel exhaust as unburnt fuel. Hydrocarbon emission and variation of $\mathrm{HC}$ with load and fuel samples are demonstrated in Figure 10. According to [Chen] hydrocarbon emission is mainly due to the fuel components trap between the crevice volumes of the combustion chamber, oxidation reaction takes place at lesser temperature, types of fuel mixture supplying into the chamber, excessively cylinder wall impingement, and loss of fuel evaporation. The hydrocarbon emission is found to be lesser for all the n-butanol-gasoline mixtures as compared to pure gasoline fuel. This is achieved due to higher molecules of oxygen presence with the n-butanol blends which further improves the combustion quality of the fuel.

However, mixing n-butanol with gasoline fuel marginally decreases the hydrocarbon emission of the engine trend is noticed for B05 mixture HC decreased by $2.25 \%, 2.72 \%$ at the part and full load, for B35 mixture decreased by $2.38 \%, 2.88 \%$ respectively at the same operating condition. The overall experimental data reveal that the n-butanol can be a potential replacement for pure gasoline fuel in terms of hydrocarbon emission. 

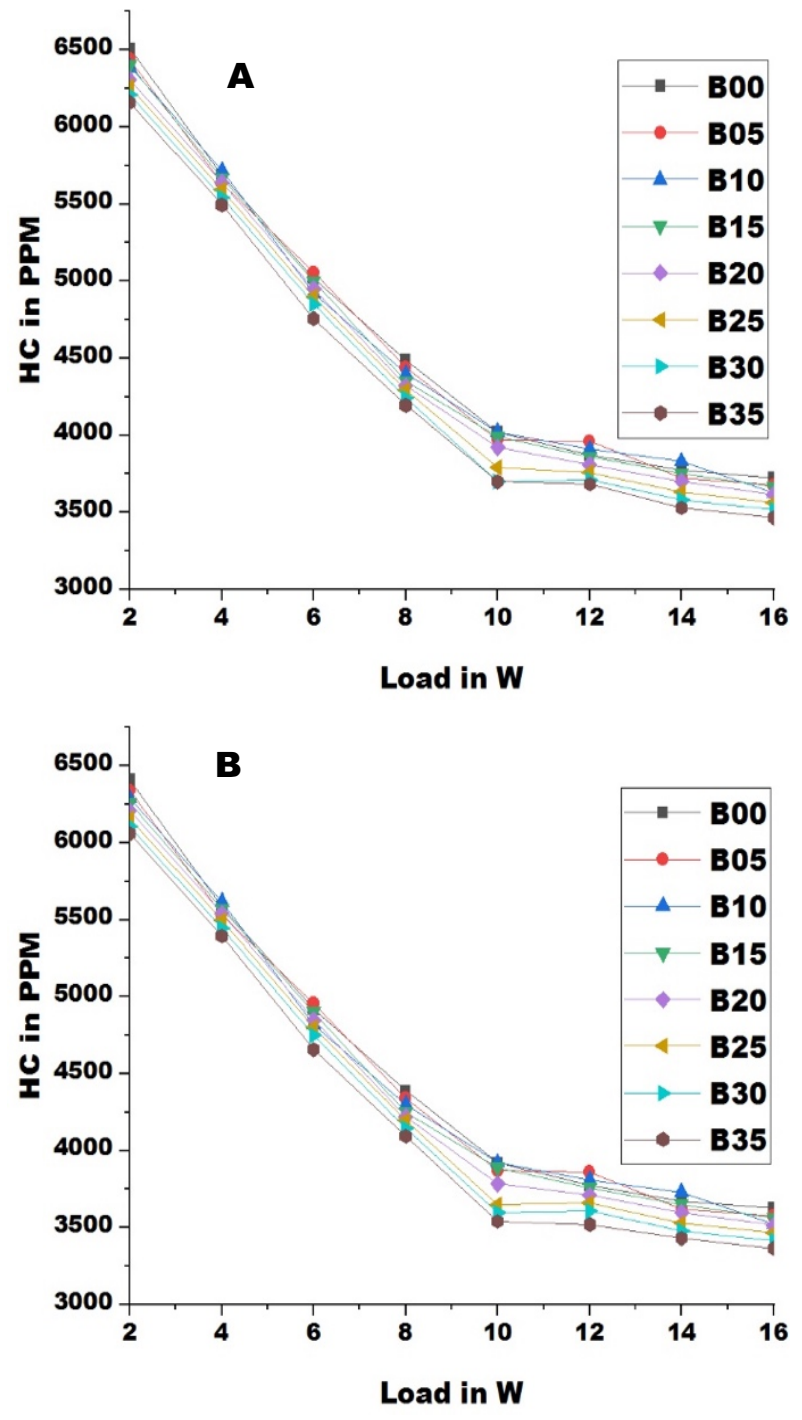

Fig. 10. Influence of $\mathrm{CR}$ on hydrocarbon (HC), (A) 10:1 \& (B) 10.5:1

3.11 Influence of compression ratio on the nitrogen oxides (NOx) emission.

Compression ignition engines are the reason for higher NOx emission because they will always work with a slightly lean mixture. The formation of NOx depends on the coefficient of surplus, concentration of oxygen, inside cylinder temperature, duration of combustion. We can notice from Figure 11, the level of NOx emission is quite higher at the part load and starts to decline towards the maximum load for all the fuel samples. The NOx emission of the B05 sample was observed to be $18.27 \%, 1.76 \%$ increases at the operational condition respectively. Similarly, for the B35 sample $5.6 \%$, 1.05 \% NOx increases at the part and full load condition. As noticed in the figure, NOx increases initially till $10 \mathrm{~W}$ load, while it decreased further. The increase in NOx is due to the greater oxygen content in the mixtures as compared to pure gasoline which leads to complete combustion of the fuel and a higher heat release rate creates higher operating temperature.
3.12 Influence of compression ratio on the oxygen $\left(\mathrm{O}_{2}\right)$ emission.

The higher rate of oxygen content in the exhaust system of the IC engine indicates the lean mixture supply to the engine cylinder and greater oxygen available with the fuel supplied. The oxygen concentration results are compared between CR's and B05, B35 blend with pure gasoline at the part and full load. An average of $10.86 \%, 11.13 \%$ increase in oxygen discharge for B05, for B35 12.71\%, $14.62 \%$ higher oxygen is noticed. The study reveals that an increase in $\mathrm{O}_{2}$ emission for all the n-butanol blends as compared to gasoline. Figure 12 demonstrates the concentration of oxygen for different fuel blends with a variable compression ratio.
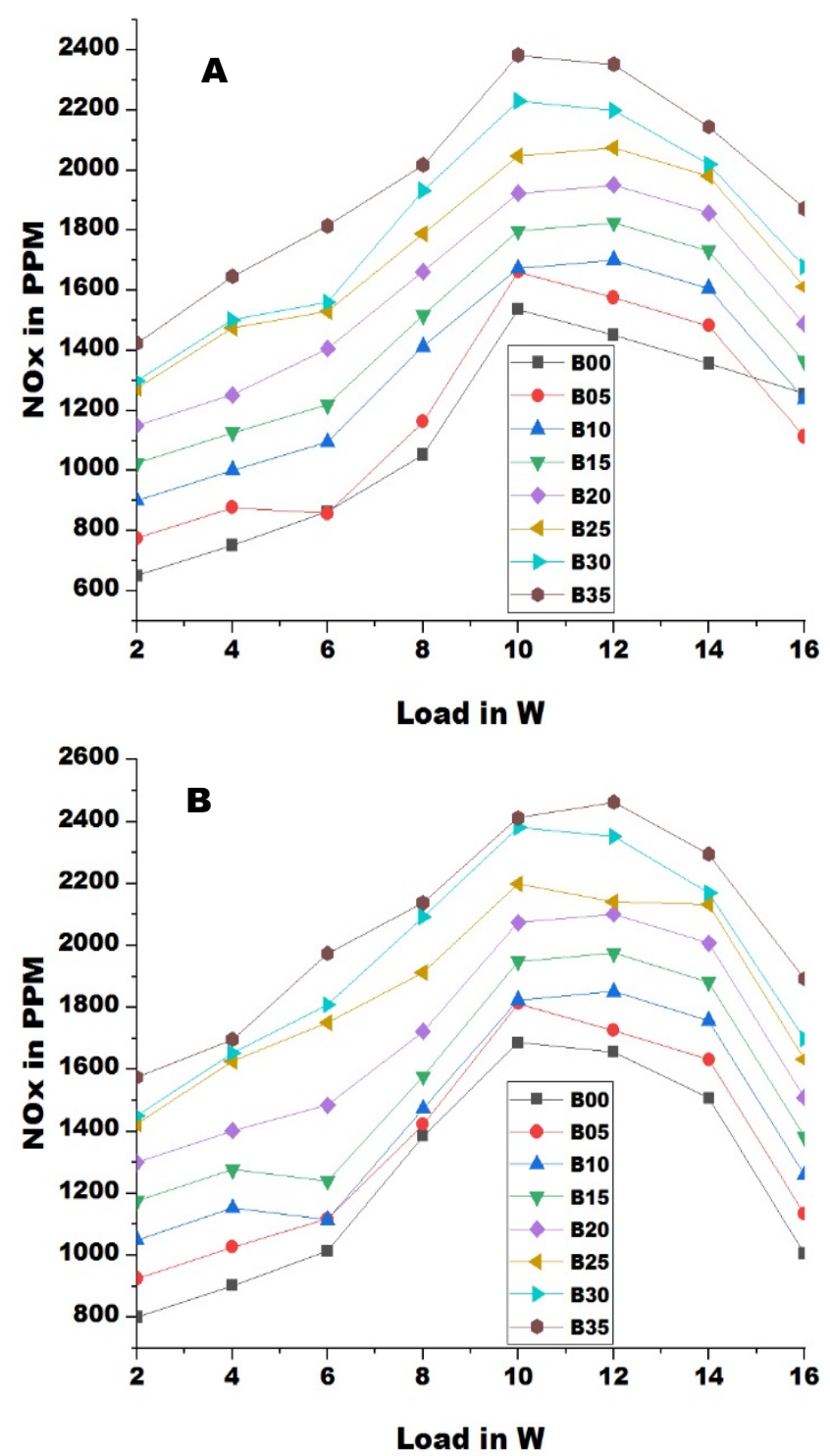

Fig. 11. Influence of CR on nitrogen oxides (NOx), (A) 10:1 \& (B) 10.5:1 

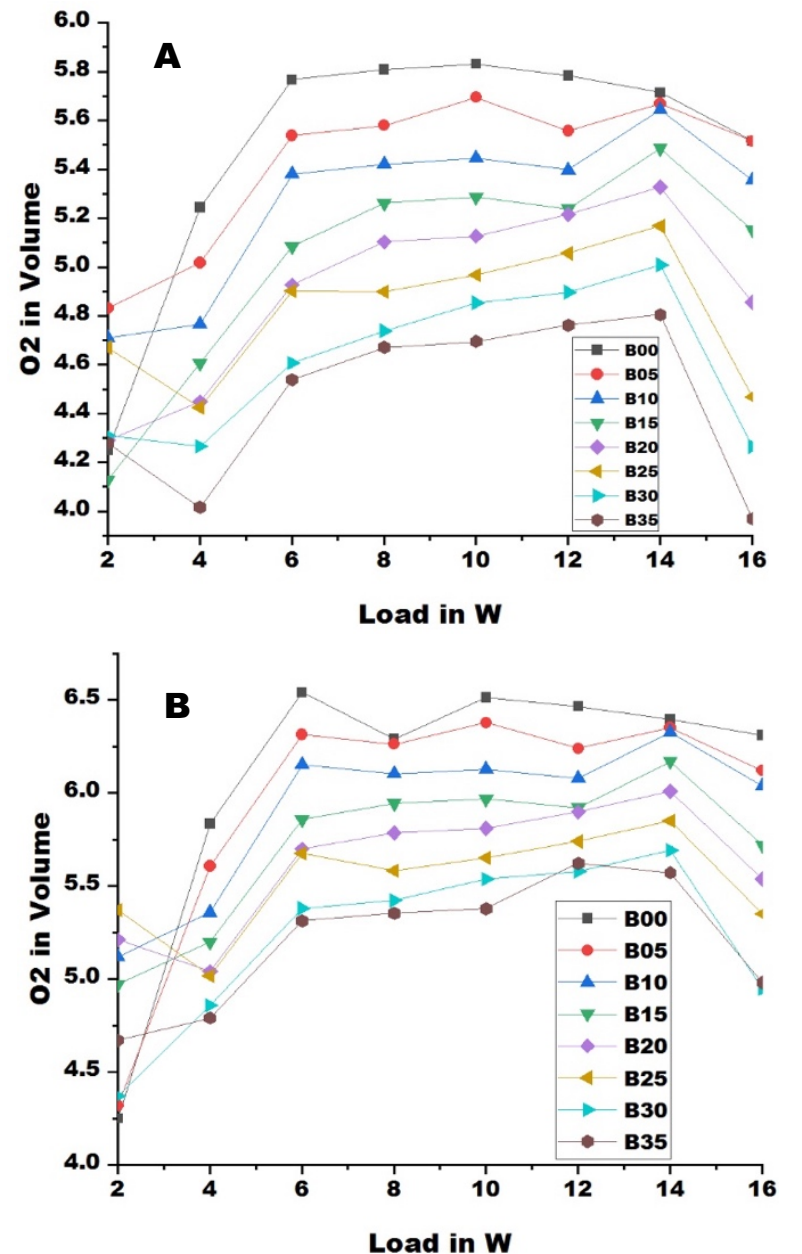

Fig. 12. Influence of CR on oxygen $\left(\mathrm{O}_{2}\right)$, (A) 10:1 \& (B) 10.5:1

\section{Conclusion}

The experimental investigations on the dual spark plug ignition engine reveal that, when the engine is facilitated with a variable compression ratio, n-butanol-gasoline blends create a greater impact on engine performance and some of the exhaust emission characteristics. The mixture B35 shows an average of $3.5 \%$ increase in indicated power for a 10.5:1 compression ratio. Improved brake power was noticed by about $3.7 \%$ for the B35 mixture. The brake thermal efficiency of the engine increased by $2.7 \%$ at full load, brake specific fuel consumption reduced by $0.11 \%$ for the B35 sample at full load. The exhaust emissions such as carbon monoxide and hydrocarbon emission are drastically reduced by $62 \%, 2.88 \%$ respectively for B35 blend at full load. However, carbon dioxide, nitrogen oxide, and oxygen emission quite higher as compared to pure gasoline at the same operating condition. Carbon dioxide increased by $14.66 \%$, nitrogen oxides increased by $1.08 \%$, and oxygen emission increased by $14.62 \%$ for B35 blend for 10.5:1 CR at the same operating condition respectively. The oxides of nitrogen can be minimized by facilitating the exhaust gas recirculation technology with the engine considerably. The study concludes that n-butanol can be considered as a potential additive fuel for the sparkignition engine, the enhancement in engine performance parameters and some of the exhaust emission are also dramatically reduced with n-butanol blended fuel samples. The production of n-butanol by adopting different technical methods can create employability in the local area, provides cheaper additive fuel for internal combustion engines.

\section{References}

Akanaw, T. T., Moges, H., G. Babu, R., Bisrat, D. (2014). Castor Seed from Melkasa Agricultural Research Centre, East Showa, Ethiopia and it's biodiesel performance in Four Stroke Diesel Engine. International Journal of Renewable Energy Development, 3(2), 99-105, http://dx.doi.org/10.14710/ijred. 3.2.99-105.

Alasfour, F. (1998). NOx emission from a spark ignition engine using 30\% iso-butanol-gasoline blend, part 1-preheating inlet air. Appl Therm Eng, 18, 245-256, https://doi.org/10.1016/ S1359-4311(97)00081-1.

Alasfour, F. (1998). NOx emission from a spark ignition engine using 30\% iso-butanol-gasoline blend, part 2-ignition timing. Appl Therm Eng, 18, 609-618, https://doi.org/10.1016/S13594311(97)00082-3.

Alasfour, F. (1999). The effect of using 30\% iso-butanol-gasoline blend on hydrocarbon emissions from a spark-ignition engine, Energy Source, 21, 379-394, https://doi.org/10. 1080/0090831 9950014704.

Amezaga, J., M, Boyes, S., Harrison, J. (2010). Biofuels policy in the European Union. In Proceedings of the 7th international biofuels conference, New Delhi, India, 1-12. New Delhi, Delhi, India, Winrock International India.

Anand, T. N., Mohan, A.M., Ravikrishna, R. V. (2012). Spray characterisation of gasoline-ethanol blends from a multi-hole port. Fuel, 102, 10, https://doi.org/10.1016/j.fuel. 2012.06.107.

Atmanlı, A., Ileri, E., Yu“ ksel, B. (2014). Experimental investigation of engine performance and exhaust emissions of a diesel engine fueled with diesel-n-butanol-vegetable oil blends. Energy Convers Manage, 81, 312-321, https://doi.org /10.1016/j.enconman.2014.02.049.

Balat, M., Balat, H. (2009). Recent trends in global production and utilization of bio-ethanol fuel. Appl Energ, 86, 2273-2282, DOI: 10.1016/j.apenergy.2009.03.015.

Chen, Gen, Wu Yu, Qianqian Li, Zuohua Huang. (2012). Effects of n-butanol addition on the performance and emissions of a turbocharged common-rail diesel engine. No. 2012-01-0852.8, SAE Technical Paper, https://doi.org/10.4271/2012-01-0852.

Chen, Z., Liu, J., Wu, Z. (2013). Effects of port fuel injection (PFI) of n-butanol and EGR on combustion and emissions of a direct injection diesel engine. Energy Convers Manage 2013, 76, 725-731, doi.10.1016/j.enconman.2013.08.030.

Chen, Z., Wu, Z., Liu, J. (2014). Combustion and emissions characteristics of high n-butanol/diesel ratio blend in a heavyduty diesel engine and EGR impact. Energy Convers Manage, 78, 787-795, doi.10.1016/j.enconman.2013.11.037.

Darmayanti, R. F., Tashiro, Y., Sakai, K., Sanomoto, K, Susanti, A., Palupi, B., Rizkiana, M. R. (2020). Biobutanol Production Using High Cell Density Fermentation in a Large Extractant Volume, International Journal of Renewable Energy Development, 9(3), 431-437, https://doi.org/10.14710/ijred. 2020. 29986.

Demirbas, A. (2009). Political, economic and environmental impacts of biofuels: a review. Appl Energy, 86, 108-117, https://doi.org/10.1016/j.apenergy.2009.04.036.

Deng, B., Fu, J., Zhang, D. (2013). The heat release analysis of bio-butanol/gasoline blends on a high speed SI (spark ignition) engine. Energy, 60, 230-241, doi.10.1016/j.energy. 2013.07.055.

Dernotte, J., Mounaim-Rousselle, C., Halter, F. (2010). Evaluation of butanol-gasoline blends in a port fuel injection, spark-ignition engine. Oil Gas Sci Technol, 65, 345-351, doi.10.2516/ogst/2009034. 
Elfasakhany, A. (2014). Experimental study on emissions and performance of an internal combustion engine fueled with gasoline and gasoline/n-butanol blends. Energy Convers Manage, 88, 277-283, doi.10.1016/j.enconman.2014.08.031.

Ganesan, V. (2012). Internal Combustion Engines, 4th edition McGraw Hill Education (India) Private Limited, ISBN-1-25900619-0.

Gao, J., Jiang, D., Huang, Z. (2007). Spray properties of alternative fuels. A comparative analysis of ethanol-gasoline blends and gasoline, Fuel, 86, 5, 1645-1650, doi:10.1016/j.fuel.2006.11. 013.

Hadiyanto, H., Aini, A. P., Widayat, W., Kusmiyati, K., Budiman, A., Rosyadi, A. (2020). Multi-Feedstock Biodiesel Production from Esterification of Calophyllum inophyllum Oil, Castor Oil, Palm Oil, and Waste Cooking Oil. International Journal of Renewable Energy Development, 9(1), 119-123, https://doi.org/10.14710/ijred.9.1.119-123.

Hoang, T. A., Le,V. V. (2017). The Performance of A Diesel Engine Fueled With Diesel Oil, Biodiesel and Preheated Coconut Oil. International Journal of Renewable Energy Development, 6(1), 1-7, http://dx.doi.org/10.14710/ijred.6.1.1-7.

Kattela, S.P., Vysyaraju, R.K.R., Surapaneni, S.R., Ganji, P.R. (2018). Effect of n-butanol/diesel blends and piston bowl geometry on combustion and emission characteristics of CI engine. Environmental Science and Pollution Research. 16611674, https://link.springer.com/article/10.1007/s11356-0183704-5.

Kolokotronis, D., Hardalupas, Y., Taylor, A., Aleiferis, P. (2010). Experimental Investigation of Cavitation in Gasoline Injectors. SAE Technical Paper 2010-01-1500, 23, doi:10. 4271/2010-01-1500.

Kuhe, A., Aliyu, S. J. (2015). Gasification of 'Loose' Groundnut Shells in a Throathless Downdraft Gasifier. International Journal of Renewable Energy Development, 4(2), 125-130, http://dx.doi.org/10.14710/ijred.4.2.125-130.

Mahfud, M., Kalsum, U., Aswie, V. (2020). Biodiesel Production through Catalytic Microwave In-situ Transesterification of Microalgae (Chlorella sp.). International Journal of Renewable Energy Development, 9(1), 113-117, https://doi.org/10.14710/ijred.9.1.113-117.

Mohite. S, Kumar, S., Maji, S. (2016). Performance characteristics of mix oil biodiesel blends with smoke emissions. International Journal of Renewable Energy Development, 5(2), 163-170, http://dx.doi.org/10.14710/ijred.5.2.163-170.

Murachman, B., Pranantyo, D., and Putra, E. S. (2014). Study of Gasohol as Alternative Fuel for Gasoline Substitution: Characteristics and Performances. International Journal of Renewable Energy Development, 3(3), 175-183, http://dx.doi. org/ 10.14710/ijred.3.3.175-183.

Padhee, D., Raheman, H. (2014). Cylinder Diesel Engine Fuelled with Blends of Jatropha Methyl Ester and Diesel.
International Journal of Renewable Energy Development, 3(2), 125-131, http://dx.doi.org/10.14710/ijred.3.2.125-131.

Pimentel, D., Patzek, T. W. (2005). Ethanol production using corn, switchgrass, and wood; biodiesel production using soybean and sunflower. Nat Resour Res 2005, 14, 65-76, https://doi.org/10.1007/s11053-005-4679-8.

Potter, M. C., Wiggert, D. C., Ramadan, B. H., Shih, T. I. P. (2012). Mechanics of fluids (Fourth edition. ed.), Cengage learning.

Ravikumar, R., \& Antony, A. J. (2020). An Experimental Investigation To Study The Performance And Emission Characteristics of n-Butanol-Gasoline Blends in a Twin Spark Ignition Engine. International Journal of Mechanical and Production Engineering Research and Development, 401-413.

Ravikumar, R., Antony, A. J. (2019). A Baseline Review on Effect of n-Butanol on the Performance and Emission Characteristics of CI and SI engines. International Journal of Scientific Engineering and Science, 3(6). 55-59, doi.10.5281/zenodo.3342082.

Ravikumar, R., Sujaykumar, G., Swetha, K. Mane, Shashidhar, A. santapur. (2018). Performance Analysis and Emission Study of a C.I. Engine using Butanol, Biodiesel and Diesel Blends. Journal of Experimental \& Applied Mechanics, 9(2), https://doi.org/10.37591/joeam.v9i2.740.

Sissine, F. (2007). Energy independence and security act of 2007. a summary of major provisions. DTIC Document.

Sorda, G., Banse, M., Kemfert, C. (2010). An overview of biofuel policies across the world. Energy Policy, 38, 6977-6988, https://doi.org/10.1016/j.enpol.2010.06.066.

Soulayman, S., Ola, D. (2019). Synthesis Parameters of Biodiesel From Frying Oils Wastes. International Journal of Renewable Energy Development, 8(1), 33-39, https://doi.org /10.14710/ijred. 8.1.33-39.

Sun, Y., Cheng, J. (2002). Hydrolysis of lignocellulosic materials for ethanol production, a review. Bioresource Technol 2002, 83, 1-11, 25. https://doi.org/10.1016/S0960-8524(01)00212-7.

Szwaja, S., Naber, J. (2010). Combustion of n-butanol in a sparkignition IC engine. Fuel 2010, 89, 1573-1582, doi:10.1016/j. fuel.2009.08.043.

Xudong Zhen, Yang Wang, Daming Liu (2019). Bio-butanol as a new generation of clean alternative fuel for SI (spark ignition) and CI (compression ignition) engines. Renewable Energy, Elsevier, vol. 147(P1), 2494-2521, https://doi.org/10.1016/j. renene.2019.10.119.

Yang,J., Yang, X., Liu, J. (2009). Dyno test investigations of gasoline engine fuelled with butanol-gasoline blends. SAE Technical Paper, http://papers.sae.org/2009-01-1891

Zhu, Y., Chen, Z., Liu, J (2014). Emission, efficiency, and influence in a diesel n-but.anol dual-injection engine. Energy Convers Manage, 87, 385-391, http://dx.doi.org/10.1016/j. enconman.2014.07.028. 